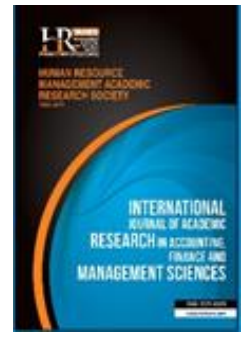

International Journal of Academic Research in Accounting, Finance and Management Sciences

Vol. 10, No.2, April 2020, pp. 184-194

E-ISSN: 2225-8329, P-ISSN: 2308-0337

(c) 2020 HRMARS

www.hrmars.com

To cite this article: Jakpar, S. Tinggi, M., Yu, T. Z. Samsudin, N. (2020). Stock Split in Insider Trading: Lessons from Malaysia., International Journal of Academic Research in Accounting, Finance and Management Sciences 10 (2):184-194.

\title{
Stock Split in Insider Trading: Lessons from Malaysia
}

\author{
Shaharudin Jakpar ${ }^{1}$, Michael Tinggi ${ }^{2}$, Tan Zhao $\mathrm{Yu}^{3}$, Norshamsiah Samsudin ${ }^{4}$ \\ ${ }^{1,2,3}$ Faculty of Economics and Business, Universiti Malaysia Sarawak, Malaysia, \\ ${ }^{1}$ E-mail: jshaharudin@unimas.my (Corresponding author) \\ ${ }^{4}$ Kementerian Pendidikan Malaysia
}

\begin{abstract}
Average daily cumulative abnormal volume turnover (ACAVT) is an interesting indicator for research purposes to determine the existence of possibly insider trading. The objective of this paper is to examine the existence of the possibly insider trading prior stock split announcement by using ACAVT. A sample of 79 public listed companies in Bursa Malaysia which did stock split within the period of 2013 to 2017 is analyzed. This paper also studies sample with positive ACAVT to determine the relationship between insider trading and independent variables which are market capitalization and major shareholder. One Sample T-Test and Multiple Regression Analysis are used in the study. The results indicate that there is $36.71 \%$ or 29 of studies sample involved in suspicious of insider trading. However, the negative value of ACAVT's mean indicates that there is no existence of possibly insider trading prior stock split announcement. Market capitalization and major shareholder are insignificant negatively associated with possibly insider trading.

Key words Stock Split, Insider Trading, Average Daily Cumulative Abnormal Volume Turnover (ACAVT)

Received: 10 May $2020 \quad$ (C) The Authors 2020

Revised: $06 \mathrm{Jul} 2020$ Published by Human Resource Management Academic Research Society (www.hrmars.com)

Accepted: $20 \mathrm{Jul} 2020$ This article is published under the Creative Commons Attribution (CC BY 4.0) license. Anyone may Published Online: $28 \mathrm{Jul} 2020 \quad$ reproduce, distribute, translate and create derivative works of this article (for both commercial and non-commercial purposes), subject to full attribution to the original publication and authors. The full terms of this license may be seen at: http://creativecommons.org/licences/by/4.0/legalcode
\end{abstract}

\section{Introduction}

Insider trading is a financial crime which comprised of fraud (Bender \& Ward, 2005). Insider trading has long been considered as obstacle and tumor in building a healthy, fair, and transparent investment environment for investors. It is a financial crime done by insiders in taking advantages from corporate event for personal benefit. In the light of insider's personal advantage scandals, insider trading activity has obtained significant attention globally and exposed to the spotlight. This issue has been appeared into sights of the public such as regulatory authority, scholars, and individual investors during these recent years. As a result, there are a set of means, method, rules and regulations that has been carried out to supervise and monitor the insider trading activities in order to protect the investors' interest and maintain the rules of game.

Latent confidence crisis which caused by furious insider trading activity and destroyed the effort of government in developing fair and smooth capital market. In some developing countries' market or known as emerging market, loose regulation would derive and furnish relatively solid space for illegal and unethical practices with ambiguous or bad result for local capital market. There are many countries have their own regulatory law to prohibit and eliminate illegal insider trading. A study shows that there are 87 out of 103 countries had enacted insider trading law to reduce the cost of equity related to insider trading (Bhattacharya \& Daouk, 2002). However, a question mark is raised on the endeavor of restraining the 